\title{
Intention to Adopt Cloud Accounting: A Conceptual Model from Indonesian MSMEs Perspectives
}

\author{
Ferdinand Murni HAMUNDU1 ${ }^{1}$, Mohd Heikal HUSIN², Ahmad Suhaimi BAHARUDIN ${ }^{3}$, Muhammad KHALEEL ${ }^{4}$
}

Received: September 10, 2020 Revised: November 02, 2020 Accepted: November 16, 2020

\begin{abstract}
Over the years, numerous Micro, Small, and Medium Enterprises (MSMEs) have been vigorously established across many countries. Even though the Internet of Things (IoT) has enabled companies to anchorage business returns, most Indonesian MSMEs are highly susceptible to failure and one of the main issues is the inability to manage their financials effectively. The literature on accounting points out that the success of MSMEs owing to the usage of cloud-based Accounting Information Systems (AIS) or Cloud Accounting (CA) could reduce the rate of failure by managing multiple accounting information at a low cost. Although many benefits exist, Indonesian MSMEs are not adopting these platforms in their daily business activities. This study investigates the factors that influence Indonesian MSMEs' intention to adopt CA. The study is directed by unstructured in-depth interviews with seven bestseller MSMEs where a thematic analysis technique was employed to identify them. The interview findings and prevailing literature on the influencing factors based on the TOE (technological, organizational, and environmental) framework to adopt CA in Indonesian MSMEs context are perceived benefits outweighing the cost, perceived compatibility, perceived complexity, owner-manager knowledge on accounting, organization size, competitive pressure, and informal network. The conceptual model further includes government intervention as a moderator in the model.
\end{abstract}

Keywords: Cloud Accounting, Intention to Adopt, Indonesian MSMEs, TOE Framework, Government Intervention

JEL Classification Code: M40, M41, M49

\section{Introduction}

According to the World Bank, MSMEs participate considerably in economic activities particularly in developing economies. Most of the global businesses belong to MSMEs that contribute to employment opportunities and economic growth. As published by International Council for Small Enterprises (ICSB), formal and informal MSMEs comprised almost 90 percent of all business entities that

${ }^{1}$ First Author. PhD Candidate, School of Computer Science, Universiti Sains Malaysia, Malaysia. Email: ferdinand@student.usm.my ${ }^{2}$ Senior Lecturer, School of Computer Science, Universiti Sains Malaysia, Malaysia. Email: heikal@usm.my

${ }^{3}$ Associate Professor, School of Computer Science, Universiti Sains Malaysia, Malaysia. Email: asuhaimi@usm.my

${ }^{4}$ Corresponding Author. PhD Candidate, School of Management, Universiti Sains Malaysia, Malaysia. Postal Address: 11800 Pulau Pinang, Malaysia] Email: kshiry2000@gmail.com

(c) Copyright: The Author(s)

This is an Open Access article distributed under the terms of the Creative Commons Attribution Non-Commercial License (https://creativecommons.org/licenses/by-nc/4.0/) which permits unrestricted non-commercial use, distribution, and reproduction in any medium, provided the original work is properly cited. contribute 70 percent of the total jobs and 50 percent of GDP on average. Over the past decades, MSMEs have been influenced by the rapidly developing economy and thus, MSMEs need an effective business strategy for the rapid changes in both business and technologies to achieve their targeted business performance. Therefore, it is no surprise that most MSMEs are constantly looking for effective methods to improve their efficiency and profitability through technology usage. One of the technologies is Go-Food, a local Sofware-as-a-Service (SaaS) platform which has a high impact on Indonesian MSMEs. Maftukhah, Rahmawati, and Fadlilah (2018) revealed that MSMEs (125,000 MSMEs approximately) had observed a hike in transactions to 2.5 times in a month after registering on Go-Food

Nevertheless, MSMEs are also vulnerable to failures originating from internal controls. Ismail and Mat Zin (2009) have identified that one of the critical factors contributing to the failure of the MSMEs is poor financial management. Though the Standard of Accounting Financial Entity without Public Accountability (SAK-ETAP) assists MSMEs to adopt standard financial reports, the financial performance of MSMEs is still not excellent. Murti (2016) 
found that MSMEs do not follow the standards reports as per SAK-ETAP. The probability of survival for small companies ( $<20$ employees) is very low, there is about $37 \%$ chance of survival in the next 4 years while the least chance of survival is $9 \%$ over the next 10 years (Mohammad, 2018). Therefore in the era of IoT, assisting in the form of training is not a viable solution and MSMEs should start investing in Accounting Information Systems (AIS) which could enhance their overall financial and organizational dexterity to reduce their failures (Mohammad, 2018). AIS has great potential to facilitate enterprises in attaining sustainable competitiveness (Lutfi, Idris, \& Mohamad, 2017). AIS plays a crucial role in enhancing and supporting various parts of business operations (Burinskienè \& Burinskas, 2010) for example, the use of management accounting information positively impact a firm's performance through the mediation of the market orientation (Do, Le, Luong, \& Tran, 2020).

The use of AIS among Indonesian MSMEs is relatively low despite several attractive benefits provided by the technology. Research conducted by the Sharing Vision on Indonesian MSMEs in 2017 found that $56 \%$ of the respondents spend about $1-2 \%$ of their revenue on IT and about $47 \%$ of the respondents spend less than USD30 a month on Internet data usage (Vision, 2017). The main constraint for MSMEs in adopting AIS is mainly financial limitations and thus, larger companies are more likely to adopt AIS compared to MSMEs (Ismail \& King, 2014). Sajady, Dastgir, and Nejad (2012) elaborated that the practice of using AIS could be more beneficial and effective when the benefits outweigh the costs of implementing such systems. In addition to that, the intention to adopt $\mathrm{CC}$ technologies and $\mathrm{CA}$ in Indonesian companies is influenced by business needs, cost effectiveness, security, and trustworthiness (Dachyar \& Prasetya, 2012).

The cloud-based AIS or CA processes and delivers financial data from remote servers of the SaaS services providers that can provide end-users with applications that operate on a cloud platform (Dimitriu \& Matei, 2015). There are several potential benefits of Software-as-a-Service (SaaS) for MSMEs as shown within the literature which include cost reduction on software license, hardware, IT personnel and maintenance, lowering the cost of ownership, increased scalability, greater utilization of resources, increased ability to focus on core business, flexibility for business innovation and improved communication with external partners (Salleh, Teoh, \& Chan, 2012). By subscribing to CA, MSMEs do not need to have a large investment in having an extensive Information Technology (IT) infrastructure. They are only required to pay for the services used by them during their business activities to the service provider.

Based on this understanding, this study focuses on behavior intention to adopt $\mathrm{CA}$ from the Indonesian
MSMEs perspective. As such, we identify the existing AIS usage and investigate the influential factors by using a qualitative study. We propose a conceptual model for understanding the determinants of the intention to adopt CA for MSMEs. The next section of this paper highlights the current SaaS used in Indonesian MSMEs and CA definitions. It will then be followed by the concept of the TOE model and the thematic analysis technique. Section 3 then proceeds with the methodology process involved in this study. The emerging issues and proposed conceptual model will be presented to emphasize its relevance to the research in Section 4 and followed by the conclusion of the study in Section 5.

\section{Background of Study}

\subsection{Indonesian MSMEs and Current SaaS Usage}

The Indonesian Ministry of Cooperatives and SMEs in 2013 highlighted that the number of MSMEs in Indonesia increased after the 1997 global economic crises and absorbed around 114 million workers, that is, about $97 \%$ of the total workforces (Anggadwita et al., 2017). This phenomenon provides sufficient support that MSMEs are a productive business in supporting and influencing Indonesia's overall economic development. These enterprises have made significant contributions to reducing unemployment, especially among youths, low-educated workers, and women (Tambunan, 2018).

Meanwhile, there are around 150 million Internet users in Indonesia and around $93 \%$ of those users have searched online for a product or service to purchase (Social, 2019). Additionally, around $90 \%$ of the users have visited an online retail store and around $86 \%$ have purchased a product or service online. Around $37 \%$ made an online purchase via a laptop or a desktop computer while $76 \%$ made an online purchase via a mobile device. It was also found that most Indonesian MSMEs are actively using social media platforms such as Facebook, Instagram, and YouTube as their marketing channels to communicate with their customers directly.

Besides, some of the MSMEs have collaborated with specific marketplaces to sell their products throughout Indonesia. For example, 'Shopee' and 'Tokopedia' which MSMEs opt to enhance service quality (Yuldinawati, van Deursen, \& van Dijk, 2018). Another platform that is widely used is Go-Jek, a motorcycle rider application that offers delivery service via their Go-Food feature. This platform has enabled food merchants to enjoy high sales (Maftukhah et al., 2018). The platform allowed microbusinesses to enter a wide market with a low budget yet high impact while creating a horizontal relationship with customers. 


\subsection{Cloud Accounting (CA)}

MSMEs access to effective accounting information is necessary to discover how well their business is doing. A previous study by Fadhil and Fadhil (2011) has shown that management accounting is necessary for the continuity of MSMEs. The improvement of management in MSMEs shall be achieved by upgrading their financial reporting system. Lussier and Halabi (2010) have highlighted that accounting records are one of the important factors in accurately determining the success or failure of enterprises.

Salehi, Abedini, and Rasouli (2012) have studied the impact of AIS on the financial performance of 118 firms listed in Iran. They found that firms with excellent AIS performance have a positive effect on overall firm performance. Moreover, Soudani (2012) studied the performance impact of AIS among 74 listed companies in the United Arab Emirates and found that AIS has a significant effect on firms' financial performance. These studies also indicated that one of the attributes that deliver success to MSMEs is by maintaining good record keeping and financial control. Therefore, the importance of using an efficient accounting system for MSMEs is undeniable (Davis, Dunn, \& Boswell, 2009).

Despite the promised benefits of AIS, Indonesian MSMEs have been slow on the system usage (Lutfi, Idris, \& Mohamad, 2016). Indeed, the Sharing Vision (2017) research found that around $32 \%$ of their respondents faced issues when they needed to maintain record-keep variances of their overall financial transactions. The respondents have recognized the importance of having reliable financial data to support their strategic decision making where around $72 \%$ of them have an intention to adopt an accounting system application.

Ionescu et al. (2013) classified AIS into three categories: (1) The first category in the $1990 \mathrm{~s}$, which entails simple applications suited for all users regardless of their size in which the data is under the client's strict control; (2) in 2000 s it was subdivided into two categories: the accounting applications locally connected to data servers while the second category has more powerful databases that enable multiple users to work simultaneously, and (3) the last category is mobile accounting software with financial dashboards which involves using mobile devices. Based on this last category, CA was introduced through the introduction of Cloud Computing (CC) which is currently considered an emerging technology. CA is an online accounting system that processes and delivers the financial data from users to remote servers owned by cloud services providers which are not limited to a single physical location (Dimitriu \& Matei, 2015). The system mainly uses the public cloud deployment model which supports the SaaS service model. This means that the CA service providers own, manage, and operate the infrastructure of the system for their customers (Dimitriu \& Matei, 2014).

To understand the MSMEs' intention to adopt or not a new technology like CA, it is important to identify the different factors that may influence the intention to adopt. This intention level for CA adoption in Indonesian MSMEs can be defined by using the TOE framework (Tornatzky \& Fleischer, 1990).

\subsection{Technology-Organization-Environment Framework}

TOE based concept had been applied as an initial guide to assure that the topic is relevant to the study. According to a review on ICT adoption and usage research by Korpelainen (2011), seven theories have been underpinned. Furthermore, it was found that the most preferred by organizations was the TOE framework (Tornatzky \& Fleischer, 1990) since such factors influence the intention to adopt technology in most organizations. A study on the adoption of IoT through demographic characteristics of managers/owners of MSMEs in Indonesia found no significance for gender and qualification but significant for age, managerial position, and years of serving in the market (Kusuma, Muafi, Aji, \& Pamungkas, 2020). This supports the organizational issue of owner-manager knowledge and scope of the organization. The literature also supports the usage of the TOE to opt IoT by government institutions and corporate sector, for example; adoption of social media in the hospitality sector in Greece (Pateli, Mylonas, \& Spyrou, 2020), intention to adopt e-government services in Malawi (Ziba \& Kang, 2020), Automation and robotics adoption by transformational organizations in Saudi Arabia (Aldossari \& Zin, 2020), and factors affecting benefits of switching to cloud-based ERP system in Taiwan (Chang, 2020). TOE provides a research model that has a strong theoretical basis and can be used in various types of research on the adoption of innovation. In the TOE framework, three factors influence the adoption of innovation, namely the technological context, organizational context, and environment context (Oliveira \& Martins, 2011). The technological context includes both internal and external technologies that are relevant to the organization. The organizational context refers to the characteristics of organizations in terms of size, the scope of business, centralization, formalization, and managerial structure, amount of resources, and connection among employees. The environmental context is the range in which the organization operates such as industry, competitors, and government (Tornatzky \& Fleischer, 1990). 


\section{Research Methodology}

In this study, a qualitative study at the organization level among the Indonesian MSMEs was conducted with several aims: 1) to examine the existing AIS usage among Indonesian MSMEs, 2) to investigate the influence factors to adopt AIS from the perspective of Indonesian MSMEs. The results are then used to propose a conceptual model for understanding the determinants of the intention to adopt cloud accounting.

The study had been conducted in Banda Aceh city which is categorized as a developing capital city in Indonesia. Seven Indonesian MSMEs that are among Banda Aceh's top bestsellers on the Go-Food merchants have been selected as the participants for our case study. In addition to that, one respondent from the Department of Cooperative \& MSME was also interviewed to support the findings of this research. In-depth interviews are inherently time-consuming. The participating enterprises were carefully selected to mitigate the effect of the small sample size (Snider, Da Silveira, \& Balakrishnan, 2009). The respondents as shown in Table 1 are the owner-managers of the MSMEs who have enjoyed the benefit of using the Go-Food application. An unstructureddepth interview in the Indonesian language was used as our primary data collection.

Table 1: Description of Participating MSMEs

\begin{tabular}{|l|c|l|c|}
\hline No & Participants & \multicolumn{1}{|c|}{ Occupation } & $\begin{array}{c}\text { Current Saas } \\
\text { Usage }\end{array}$ \\
\hline 1. & C1 & Owner & $\begin{array}{c}\text { Go-Food, } \\
\text { Instagram }\end{array}$ \\
\hline 2. & C2 & Owner & Go-Food \\
\hline 3. & C3 & Owner & Go-Food \\
\hline 4. & C4 & Owner & Go-Food \\
\hline 5. & C5 & Owner & $\begin{array}{c}\text { Instagram, } \\
\text { Go-Food }\end{array}$ \\
\hline 6. & C6 & Manager & Instagram, \\
Go-Food \\
\hline 7. & C7 & Owner & Instagram, \\
\hline 8. & Go-Food \\
\hline
\end{tabular}

The main flow of a process for the data by using the thematic analysis technique is depicted in Figure 1 (Miles et al., 1994). The data analysis process was carried out by initially selecting data that is related. The topic is based on the main aim of the study which is the adoption of CA among the Indonesian MSMEs. If the data is not related, then the data would be discarded. On the other hand, if the data has similar concepts to the identified topic, it will be coded in the coding process. Our study has utilized an in-depth interview approach and extracted the relevant data. During the in-depth interview session, we had audio recorded the interviews as well as took additional field notes. All of the original data was noted based on the result of interviews and referred to the formulation of the problem, the purpose, and focus of the study, supporting theories, and the previous research on this stage. Then, the code pattern is identified and coded using NVivo software. A credibility test is also carried out on the data by using the triangulation approach. For instance, to compare and match interviews with each other. Besides, the results of the interviews have been cross-checked with the related references and through validation using qualitative methods. This ensures that the data obtained has a high level of validity.
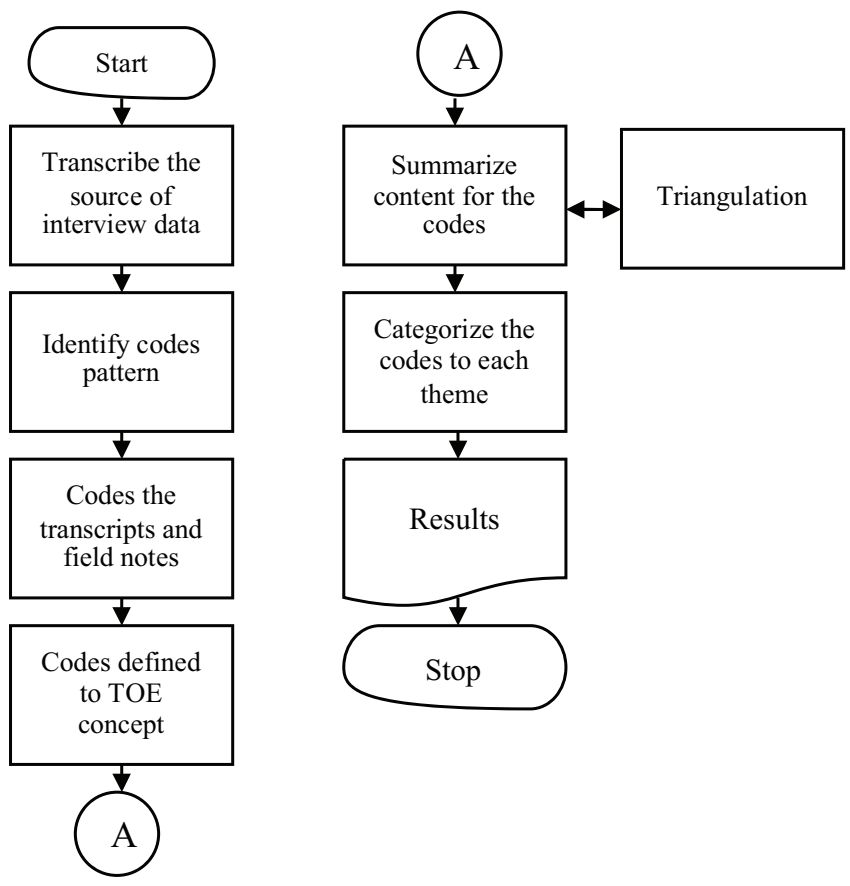

Figure 1: Overall Process of Data Analysis 


\section{Results and Discussion}

\subsection{Existing AIS Usage Among Indonesian MSMES}

To build an understanding of the AIS adoption, respondents were interviewed to indicate the use of accounting information, their perception, and the adoption of AIS if there is any. This theme is categorized into two code factors. The code factors are, (1) Perception of SAK-ETAP, and (2) Perception of AIS.

\subsubsection{Perception of Standard of Accounting Financial Entity without Public Accountability (SAK- ETAP) (This code can be described as Indonesian MSMEs behavior towards SAK-ETAP)}

The government particularly the Department of Cooperative and Small-scale Enterprises does not know what type of financial statements are generated by the MSMEs, whether they do record-keeping or not, and whether their financial reports follow SAK-ETAP or not. There is a lack of knowledge about SAK-ETAP among most Indonesian MSMEs as per respondent G's statement below.

"We don't know which kind of financial report form is applied by MSMEs, whether following SAK-ETAP, systematic, accurate, and reliable... We need to identify what they have generated about financial reporting, how they have recordedkeeping, and what items are recorded in the bookkeeping or if it is on their memory only."

Haryani (2012) found that MSMEs are still not familiar with preparing financial reports based on SAK-ETAP even though the SAK-ETAP has been implemented in January 2010. There are obstacles in generating standardized financial reports such as inappropriate infrastructures of accounting, human resources, and education (Yanto et al., 2017) while the external factors are lack of participation of government institutions and SMEs (Ermawati, 2018).

\subsubsection{Perception of AIS (All respondents realize the benefits of this technology if successfully implemented)}

Based on the interview, all respondents agreed that if CA is well-implemented, it will be an important potential for the enterprise's future. However, the lack of information about the technology provider and cost issues are the main constraints to adopt AIS. Below is a statement by the respondent C6.

"We are aware of the benefits of computerized accounting but lack information about the service provider...So far, we only focus on sales and marketing and have less concern about record-keeping."

The above is in line with the previous study by Lind (2006) who identified that the lack of information about the technology available and its uses, capabilities, and return on investment is a greater barrier to technology adoption. The service providers should be more enthusiastic to educate and socialize the benefits of CA by offering a free trial, run simulations in organization setup, and practical solutions to cater to business needs (Adiyasa et al., 2018).

\subsection{Proposed Conceptual Model}

Furthermore, the result of data analysis is presented by compiling a series of interviews into the matrix. Based on the data analysis, a conceptual model was then developed for understanding the determinants of the intention to adopt cloud accounting. Based on the in-depth interview sessions, we proposed a conceptual model that highlights the factors that influence Indonesian MSMEs' intention to adopt CA. Three major themes have been determined namely technological, organizational, and environment. For each of the themes, we have identified several sub-categories that were derived from our data collection.

\subsubsection{Emerged Themes}

The group of sub-categories related to factors that influence Indonesian MSMEs' intention to adopt CA is represented by each theme based on the interviews conducted at seven business organizations. Table 2 depicts the emerged themes and sub-categories that were derived from the data analysis stage as well as the credibility test by using the triangulation approach.

The emerged themes, and sub-categories, regarding the factors that influence an intention to adopt CA, is described as below:

Technological Related Factors: Tornatzky and Fleischer (1990) described technology as both internal and external technologies relevant to the enterprise. These themes are divided into three categories of sub-categories which are perceived benefit outweighs the cost, perceived compatibility, and perceived complexity.

\section{(1) The perceived benefit outweighs the cost.}

The perceived benefit is whether the benefit outweighs the costs or not. In the CA adoption intention context, it refers to the degree to which the CA is perceived as providing greater benefit rather than a cost for MSMEs. All respondents stated that this factor must be considered before adopting the technology. 
Table 2: Emerged Themes and Sub-Categories

\begin{tabular}{|l|l|l|}
\hline Category/Theme & \multicolumn{1}{|c|}{ Sub-categories } & \multicolumn{1}{c|}{ Credibility Test } \\
\hline \multirow{5}{*}{ Technological Issues } & $\begin{array}{l}\text { Perceived Benefit } \\
\text { Outweigh Cost }\end{array}$ & $\begin{array}{l}\text { All respondents (Benlian \& Hess, 2011; Meroño-Cerdán, 2017; } \\
\text { Venters \& Whitley, 2012) }\end{array}$ \\
\cline { 2 - 3 } & Perceived Compatibility & $\begin{array}{l}\text { All respondents (Chau \& Deng, 2018; Mohammad, 2018; Shah } \\
\text { Alam, 2009; Thong, 1999) }\end{array}$ \\
\cline { 2 - 3 } Organizational Issues & Perceived Complexity & $\begin{array}{l}\text { All respondents (Al-Qirim, 2007; Azam \& Taylor, 2013; Teo, Lin, } \\
\text { \& Lai, 2009) }\end{array}$ \\
\cline { 2 - 3 } & $\begin{array}{l}\text { Owner-Manager } \\
\text { knowledge accounting }\end{array}$ & G, (Wan Ismail \& Mokhtar, 2016) \\
\cline { 2 - 3 } & Organization size & $\begin{array}{l}\text { All respondents (Alshamaila, Papagiannidis, \& Li, 2013; } \\
\text { Low, Chen, \& Wu, 2011; Misra\& Mondal, 2011; Oliveira, } \\
\text { Thomas, \& Espadanal, 2014) }\end{array}$ \\
\hline \multirow{5}{*}{ Environmental Issues } & Informal Network & $\begin{array}{l}\text { All respondents (Allinson, 2004; Lutfi et al., 2016; Sitorus, } \\
\text { Govindaraju, Wiratmadja, \& Sudirman, 2019) }\end{array}$ \\
\cline { 2 - 3 } & Competitive Pressure & $\begin{array}{l}\text { All respondents (IntanSalwani, Marthandan, DaudNorzaidi, \& } \\
\text { Choy Chong, 2009; Lutfi et al., 2017; Zhu \& Kraemer, 2005) }\end{array}$ \\
\hline
\end{tabular}

“... We shall adopt a mobile application to support recordkeeping if we get it at a suitable price since our business is micro-size." (C2)

Based on the above finding, this study predicts that the greater the perceived benefit outweighs the cost, the more likely that Indonesian MSMEs will adopt CA. Therefore, this study hypothesizes that:

H1a: There is a positive relationship between perceived benefit outweighs the cost and Indonesian MSMEs' intention to adopt $C A$.

\section{(2) Perceived Compatibility.}

Perceived compatibility is another technological characteristic perceived by MSMEs as a degree to which a new technology meets the habits, values, and needs (Rogers, 2010). In the context of Indonesian MSMEs as merchants of Go-Food, the new system is expected to be compatible and integrated with the Go-Food application.

"At Go-Food application, we shall receive a bill of the $20 \%$ sharing revenue from Go-Food on a monthly basis along with the details of sales. The majority of our sales via the Go-Food application and some of the cooking ingredients purchased via the Go-Shop application are also is under Go-Jek service. Unfortunately, Go-Jek has not provided an accounting application yet. It shall be easy if everything is under one service." (C1)

Some prior scholars found that IT adoption and usage is significantly influenced by IT compatibility (Chau \& Deng, 2018; Mohammad, 2018; Shah Alam, 2009). When a new technology is recognized as compatible with the current work application systems, Indonesian MSMEs are likely to consider the technology. Therefore, this study hypothesizes:

H1b: There is a positive relationship between perceived compatibility and Indonesian MSMEs' intention to adopt $C A$.

\section{(3) Perceived Complexity.}

Perceived complexity is the degree to which a system is perceived as difficult to use. Lack of basic accounting knowledge is one barrier in keying data (Ismail, 2009). In the context of CA adoption intention, all respondents expect that the technology is user-friendly even in the background of accounting discipline.

"My major is public health instead of accounting... A good application if we just click in handphone, and also just key-in the sales and purchase transaction as what we understand." (C3)

Based on the above issue, this study describes that the complexity of an innovation is an inhibitor that discourages greater usage. The following hypotheses therefore formulated:

H1c: There is a negative relationship between perceived complexity and Indonesian MSMEs' intention to adopt $C A$.

Organizational Related Factors: This theme focuses on the internal factors of an organization which are the characteristics and resources of the organization (Tan, 2010). These themes are divided into three categories of sub-categories which are owner-manager knowledge of accounting and organization size. 


\section{(1) Owner-manager knowledge of accounting.}

The constraint of MSMEs on the accounting application adoption is based on the education level of the ownermanager. However, the owner-manager should not only be well-versed in accounting but also be enthusiastic in spreading accounting awareness by conducting training \& workshops in collaboration with government officials.

"There are numerous MSMEs that have succeeded in producing, marketing, and achieving sales targets but failed to maintain their business due to lack of understanding in managing their finances. Therefore, the Government should encourage the owner-manager of MSMEs to change their mindsets to be aware of the accounting benefit. Besides, there is an accounting standard for MSMEs that simple and can be easily applied." respondent G.

Based on the emerged code, this study predicts that the more awareness of Indonesian MSMEs on the accounting benefit, the higher a chance that they will adopt the CA. The following hypotheses therefore formulated:

H2a: There is a positive relationship between ownermanager knowledge on accounting and Indonesian MSMEs' intention to adopt $C A$.

\section{(2) Organization Size.}

In the context of CA adoption intention, accounting is a must for MSMEs or large-scale business. However, all respondents described that the generation of standard financial statements is only for large-scale enterprises.

"Well, I did not generate a standard financial statement ...Ours was just a simple report, unlike the large-scale companies." (C6)

In contrast, Alshamaila, Papagiannidis, and Li (2013) stated that start-ups and small businesses tend to adopt cloud services. Misra and Mondal (2011) reported that MSMEs were highly suitable to use the cloud since MSMEs are more agile and flexible and adapt to change more quickly. Hence, this study hypothesizes that:

H2b: There is a negative relationship between organization size and Indonesian MSMEs' intention to adopt CA.

Environment Related Factors: The environmental factors refer to external influences such as pressures from customers, suppliers, and competitors as well as the external support that influence the adoption of technologies. These themes are divided into two categories which are (1) Networking (informal), and (2) Competitive Pressure.

\section{(1) Informal network,}

The intention to adopt CA is influenced by the strong relationship between the owner-manager of MSMEs in the informal community who always share advice, consultations, and information about their businesses. All respondents stated that the reason for using an application is because of the advice from their friends. In the context of CA adoption intention, the respondent of $\mathrm{C} 5$ shares his situation.

"Nowadays, we are in the process of adopting Pawon; an accounting application on yearly basis rent... We are still on trial and my friend said that there are no issues on Pawon... we can trash the transaction history and monitor the business by using a mobile application. There is only one issue, which is the workers'attitude."

Sitorus et. al (2019) stated that Indonesian MSMEs while making a decision for adopting technology were influenced by social community relations. Furthermore, the informal network is expected to have a great role in advising MSMEs about AIS (Lutfi et al., 2016). Therefore, this study hypothesizes that:

H3a: There is a positive relationship between the informal network and Indonesian MSMEs' intention to adopt CA.

\section{(2) Competitive Pressure.}

In the context of technology adoption intention, as the level of pressure from competitors running the same business increases and if business competitors adopt technology, in such cases, MSMEs also adopt technology. Most of the respondents have utilized technology such as Instagram \& Facebook and as Go-Food Merchants because they follow the trends.

"Most restaurants and Cafes in Banda Aceh have enjoyed Pawon. It is different from Traditional Coffee Shop which is conventional. Pawon is more expensive but more reliable than others. " responded by $\mathrm{C} 5$

Lutfi et al. (2017) concluded that enterprises shall be forced to adopt AIS when competitors start to use it. Even from the customer side, the trend of digital payments is growing in Indonesia and the IoT facilities can aid digital payment by superseding cash payments (Yucha et al., 2020). When Indonesian MSMEs fear losing their competitiveness, they may consider adopting CA. Therefore, this study hypothesizes that:

H3b: There is a positive relationship between competitive pressure and Indonesian MSMEs' intention to adopt CA. 


\subsubsection{Government Intervention as Moderator Variable}

In a developing nation, such as Indonesia, government intervention plays a necessary role to motivate MSMEs to adopt IT services. The introduction of innovation in MSMEs can be encouraged by government policies or the provision of related assistance for organizations to adopt such technologies (Kousaret et al., 2017). For instance, the government could provide capital access at a lower rate to stimulate the development of MSMEs. Regarding the policy, Indonesian MSMEs may also consider adopting CA due to the ability to support financial reporting activities. Besides, governments can encourage the adoption of IT in MSMEs by providing training, guidelines, financial assistance, technical support, independent advice, and other incentives (Abdul Hameed \& Counsell, 2012; Yanto et al., 2017).

With the re-enactment of the Ministry of Finance Regulation No. 210/PMK.010/2018 on Tax Treatment of Trade Transactions through Electronic Systems (e-Commerce) (Budiarto \& Cahyono, 2019) which was subjected to the Indonesian E-Commerce Association survey, these laws should encourage Indonesian MSMEs to adopt CA. Upon closer examination on the moderating role of government intervention in the context of a developing country such as Cambodia, Mohd Shariff, Peou and Ali (2010) concluded that government intervention does play a significant moderating role between internal factors such as an entrepreneurial value, management, and market strategies, and the growth performance of SMEs. However, no studies have investigated the moderating role of government intervention between TOE factors and the CA adoption intention, especially in the case of Indonesian MSMEs. This study aims to propose the moderating role of government intervention rather than considering it as one of the independent factors influencing Indonesian MSMEs' intention to adopt CA.

\section{Conclusion}

Our results have concluded that the adoption rate of CA among Indonesian MSMEs is relatively low, but the respondents are aware of the benefits of CA. The issue of the low adoption rate is due to a lack of information about the availability of CA technology. Several factors that influence Indonesian MSMEs' intention to adopt CA, especially with government interventions, have been revealed. In the technological context, this study found that the greater the perceived benefit outweighs the cost, the more likely that Indonesian MSMEs will adopt CA. Besides, Indonesian MSMEs are likely to adopt the technology if the new technology is recognized as compatible with current work application systems and at low complexity. There are two factors in the organizational context which are ownermanager knowledge of accounting and the organization size. Moreover, there are also two factors in the environmental context which are informal network and competitive pressure.

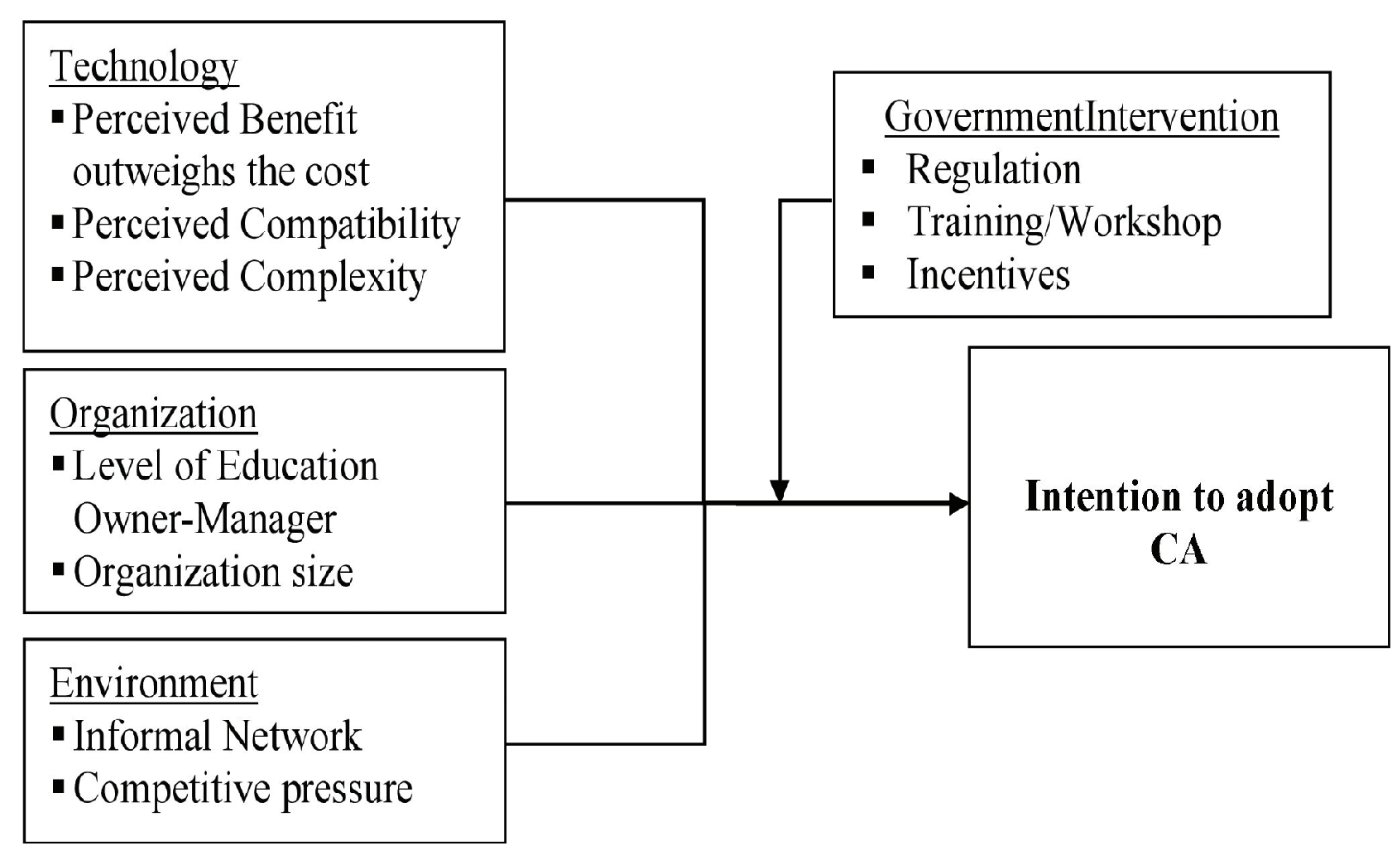

Figure 2: Conceptual Model of CA Adoption Intention in Indonesian MSMEs 
Additionally, our proposed conceptual model allows the researchers to empirically test and determine the appropriate specification in the context of adoption intention toward CA particularly among the Indonesian MSMEs and in other developing countries. However, there are some limitations to this study that might constrain the generalizability. The study was based on only seven of the top MSMEs on the Go-Food platform in Banda Aceh city. Thus, the results might not be generalized especially in other cities of the developing countries. Secondly, the study focused on culinary businesses whereas there is a large number of MSMEs in Indonesia. As such, there is an opportunity to replicate this study across different cities and other smallscale industries.

At the moment, our study is in the preliminary stage, and thus, a subsequent empirical study among Indonesian MSMEs to validate the proposed conceptual model would need to be conducted by future researchers. The result of the future study can be used as a globalized benchmark for MSMEs in developing countries.

\section{References}

Abdul Hameed, M., \& Counsell, S. (2012). Assessing the influence of environmental and CEO characteristics for adoption of information technology in organizations. Journal of Technology Management \& Innovation, 7(1), 64-84.

Adiyasa, H., Hidayanto, A. N., Pinem, A. A., Solikin, Negara, E. S., \& Putri, P. B. M. (2018). Exploring the factors for cloud computing adoption in Indonesia. 2018 International Conference on Computing, Engineering, and Design, 72, 137-142. https://doi.org/10.1109/ICCED.2018.00035

Aldossari, M., \& Zin, A. M. (2020). Automation and robotics system (ARS) adoption in the transformational companies in the kingdom of Saudi Arabia: A conceptual framework. Journal of Theoretical and Applied Information Technology, 98(16), 3245-3269.

Allinson, G., Braidford, P., Grewer, N., Houston, M., Orange, R., Sear, L., \& Stone., I. (2004). Ethnic Minority Businesses and ICT. Durham Business School: Focus Group Research.

Alshamaila, Y., Papagiannidis, S., \& Li, F. (2013). Cloud computing adoption by SMEs in the north east of England: A multi-perspective framework. Journal of Enterprise Information Management, 26(3), 250-275. https://doi. org/10.1108/17410391311325225

Anggadwita, G., Luturlean, B. S., Ramadani, V., \& Ratten, V. (2017). Socio-cultural environments and emerging economy entrepreneurship: Women entrepreneurs in Indonesia. Journal of Entrepreneurship in Emerging Economies, 9(1), 85-96. https://doi.org/10.1108/JEEE-03-2016-0011

Benlian, A., \& Hess, T. (2011). Opportunities and risks of softwareas-a-service: Findings from a survey of IT executives. Decision Support Systems, 52(1), 232-246.
Budiarto, M. T., \& Cahyono, B. (2019). Examining the obligations of marketplace platform providers and traders as taxable entrepreneurs in the electronic transaction trading business (e-commerce). Paper presented at the proseding seminar nasional akuntansi.

Burinskienė, A., \& Burinskas, A. (2010). Investments into e-business technologies. Economics \& Management, 2010, 886-892

Chang, Y. W. (2020). What drives organizations to switch to cloud ERP systems? The impacts of enablers and inhibitors. Journal of Enterprise Information Management, 33(3), 600-626. https://doi.org/10.1108/JEIM-06-2019-0148

Chau, N. T., \& Deng, H. (2018). Critical determinants for mobile commerce adoption in Vietnamese SMEs: A conceptual framework. Procedia Computer Science, 138, 433-440. https:// doi.org/10.1016/j.procs.2018.10.061

Dachyar, M., \& Prasetya, M. D. (2012). Cloud computing implementation in Indonesia. International Journal of Applied Science and Technology, 2(3), 138-142.

Davis, D., Dunn, P., \& Boswell, K. (2009). The importance of capturing and using financial information in small business. American Journal of Economics and Business Administration, 1(1), 27-33.

Dimitriu, O., \& Matei, M. (2014). The expansion of accounting to the cloud. SEA-Practical Application of Science, 2(4), 237240.

Dimitriu, O., \& Matei, M. (2015). Cloud accounting: a new business model in a challenging context. Procedia Economics and Finance, 32, 665-671.

Do, T. H., Le, H. M., Luong, D. T. T., \& Tran, Q. T. (2020). Relationship between the management accounting information usage, market orientation and performance: Evidence from Vietnamese tourism firms. Journal of Asian Finance, Economics and Business, 7(10), 707-716. https://doi.org/10.13106/ jafeb.2020.vol7.no10.707

Ermawati, E. (2018). Preparation of financial statements based on Financial Accounting Standards Entity without Public Accountability (SAK-ETAP) Case Study at SMEs CV. Kreasindo Prima Lumajang Emmy. In Intergovernmental Panel on Climate Change (Ed.), The 2nd International conference on economics and business (pp. 183-190). Retrieved from https:/www.cambridge.org/core/product/identifier/CBO9781 107415324A009/type/book_part

Fadhil, N. F. M., \& Fadhil, N. F. M. (2011). Managing company's financial among small and medium non-manufacturing companies. Far East Journal of Psychology and Business, 2(2), 17-36.

Haryani, E. (2012). Accounting system for small business in Indonesia: Case study on convection business in Tingkir Lor Village. Researchers World, 3(2), 104.

Ionescu, B., Ionescu, I., Bendovschi, A., \& Tudoran, L. (2013). Traditional accounting vs. cloud accounting. Paper presented at the Proceedings of the 8th International Conference: 
Accounting and Management Information Systems, Bucharest, Romania.

Ismail, N. A. (2009). Factors influencing AIS effectiveness among manufacturing SMEs: Evidence from Malaysia. The Electronic Journal of Information Systems in Developing Countries, 38(1), 1-19.

Ismail, N. A., \& King, M. (2014). Factors influencing the alignment of accounting information systems in small and medium sized Malaysian manufacturing firms. Journal of Information Systems and Small Business, 1(1-2), 1-20.

Ismail, N. A., \& Mat Zin, R. (2009). Usage of accounting information among Malaysian Bumiputra small and medium non-manufacturing firms. Journal of Enterprise Resource Planning Studies, 2009, 1-7.

Korpelainen, E. (2011). Theories of ICT system implementation and adoption: A critical review.

Kousar, S., Sabri, P. S. U., Zafar, M., \& Akhtar, A. (2017). Technological factors and adoption of green innovation: Moderating role of government intervention: A case of SMEs in Pakistan. Pakistan Journal of Commerce and Social Sciences, 11(3), 833-861.

Kusuma, H., Muafi, M., Aji, H. M., \& Pamungkas, S. (2020). Information and communication technology adoption in small- and medium-sized enterprises: Demographic characteristics. Journal of Asian Finance, Economics and Business, 7(10), 969-980. https://doi.org/10.13106/ jafeb.2020.vol7.no10.969

Lind, P. (2006). Computerization in developing countries. London, UK: Routledge.

Lussier, R. N., \& Halabi, C. E. (2010). A three-country comparison of the business success versus failure prediction model. Journal of Small Business Management, 48(3), 360-377. https://doi.org/ 10.1111/j.1540-627X.2010.00298.x

Lutfi, A. A., Idris, K. M., \& Mohamad, R. (2016). The influence of technological, organizational and environmental factors on accounting information system usage among Jordanian Small and Medium-sized Enterprises (SMEs). International Journal of Economics and Financial Issues, 6(7S), 240-248.

Lutfi, A. A., Idris, K. M., \& Mohamad, R. (2017). AIS usage factors and impact among Jordanian SMEs: The moderating effect of environmental uncertainty. Journal of Advanced Research in Business and Management Studies, 6(1), 24-38.

Maftukhah, I., Rahmawati, F. D., \& Fadlilah, A. (2018). Considering the influence of digital promotion performed by Go-Jek Indonesia and $\mathrm{C} 2 \mathrm{C}$ marketplaces on buyers' purchasing decision. KnE Social Sciences, 2018, 541-552.

Meroño-Cerdán, A. L. (2017). Perceived benefits of and barriers to the adoption of teleworking: peculiarities of Spanish family firms. Behaviour \& Information Technology, 36(1), 63-74. https://doi.org/10.1080/0144929X.2016.1192684

Miles, M. B., Huberman, A. M., Huberman, M. A., \& Huberman, M. (1994). Qualitative data analysis: An expanded sourcebook. Thousand Oaks, CA: Sage Publications.
Misra, S. C., \& Mondal, A. (2011). Identification of a company's suitability for the adoption of cloud computing and modelling its corresponding Return on Investment. Mathematical and Computer Modelling, 53(3-4), 504-521. https://doi. org/10.1016/j.mcm.2010.03.037

Mohammad, A. A. (2018). An exploration of accounting information system's role in SMEs failure triangular. International Journal of Agile Systems and Management, 11(2), 155-178. https://doi. org/10.1504/IJASM.2018.092546

Mohd Shariff, M. N., Peou, C., \& Ali, J. (2010). Moderating effect of government policy on entrepreneurship and growth performance of small-medium enterprises in Cambodia. International Journal of Business and Management Science, 3(1), 57.

Murti, G. T. (2016). Society assistance financial report based on financial accounting standard of entities without public accountability standard in encouraging small and middle enterprises development. International Journal of Scientific \& Technology Research, 5(4), 99-105.

Oliveira, T., \& Martins, M. F. (2011). Literature review of information technology adoption models at firm level. Electronic Journal of Information Systems Evaluation, 14(1), 110.

Pateli, A., Mylonas, N., \& Spyrou, A. (2020). Organizational adoption of social media in the hospitality industry: An integrated approach based on DIT and TOE frameworks. Sustainability, 12(17), 7132. https://doi.org/10.3390/su12177132

Rogers, E. M. (2010). Diffusion of innovations. New York, NY: Simon and Schuster.

Sajady, H., Dastgir, M., \& Nejad, H. H. (2012). Evaluation of the effectiveness of accounting information systems. International Journal of Information Science and Management (IJISM), 6(2), 49-59.

Salehi, M., Abedini, B., \& Rasouli, A. (2012). Association of accounting information system and companies' performance: Iranian evidence. Archives Des Sciences, 65(7), 93-103.

Salleh, S. M., Teoh, S. Y., \& Chan, C. (2012). Cloud enterprise systems: A review of literature and its adoption. Paper presented at the PACIS.

Shah Alam, S. (2009). Adoption of internet in Malaysian SMEs. Journal of Small Business and Enterprise Development, 16(2), 240-255.

Sitorus, H. M., Govindaraju, R., Wiratmadja, I. I., \& Sudirman, I. (2019). Examining the role of usability, compatibility and social influence in mobile banking adoption in Indonesia. International Journal of Technology, 10(2), 351-362. doi:10.14716/ijtech.v10i2.886

Snider, B., Da Silveira, G. J., \& Balakrishnan, J. (2009). ERP implementation at SMEs: Analysis of five Canadian cases. International Journal of Operations \& Production Management, 29(1), 4-29. https://doi.org/10.1108/01443570910925343

Social, W. A. (2019). Digital in 2019: Indonesia. Retrieved from https://datareportal.com/reports/digital-2019-indonesia 
Soudani, S. N. (2012). The usefulness of an accounting information system for effective organizational performance. International Journal of Economics and Finance, 4(5), 136-145.

Tambunan, T. T. (2018). MSMEs and access to financing in a developing economy: The Indonesian experience. In A. Woldie $\&$ B. Thomas, Financial entrepreneurship for economic growth in emerging nations (pp. 148-172). South Wales, UK:IGI Global.

Tan, T. C. F. (2010). A perception-based model for technological innovation in small and medium enterprises. Paper presented at the 18th European Conference on Information Systems.

Tornatzky, L., \& Fleischer, M. (1990). The process of technology innovation. Lexington, MA: Lexington Books.

Venters, W., \& Whitley, E. A. (2012). A critical review of cloud computing: Researching desires and realities. Journal of Information Technology, 27(3), 179-197. https://doi. org/10.1057/jit.2012.17

Vision, S. (2017). Sharing vision research - GO-FOOD dan Geliat Ekonomi Digital di UKM. . Retrieved from https://inet.detik.com/ business/d-3641906/go-food-dan-geliat-ekonomi-digital-di-ukm

Wan Ismail, W., \& Mokhtar, M. (2016). Application of TOE framework in examining the factors influencing pre and post adoption of CAS in Malaysian SMEs. International Journal of Information Technology and Business Management, 49(1), 26-37.

Yanto, H., Yulianto, A., Sebayang, L. K. B., \& Mulyaga, F. (2017). Improving the compliance with accounting standards without public accountability (SAK ETAP) by developing organizational culture: A case of Indonesian SMEs. Journal of Applied Business Research, 33(5), 929. https://doi. org/10.19030/jabr.v33i5.10016.

Yucha, N., Setiawan, S., Muttaqiin, N., Ekasari, R., \& Mauladi, K. F. (2020). digital payment system analysis of buying decision in Indonesia. Journal of Asian Finance, Economics and Business, 7(10), 323-328. https://doi.org/10.13106/jafeb.2020. vol7.n10.323

Yuldinawati, L., van Deursen, A. J., \& van Dijk, J. A. (2018). Exploring the Internet Access of Indonesian SME Entrepreneurs. International Journal of Business, 23(3), 235-247.

Ziba, P. W., \& Kang, J. (2020). Factors affecting the intention to adopt e-government services in Malawi and the role played by donors. Information Development, 36(3), 369-389. https://doi. org/10.1177/0266666919855427 